\title{
Criminal Liability of Political Parties in Corruption Criminal Offense
}

\author{
Prima Sophia Gusman; Oce Madril \\ Universitas Gadjah Mada, Indonesia \\ http://dx.doi.org/10.18415/ijmmu.v8i10.3087
}

\begin{abstract}
This research aims to analyze the criteria of political parties' criminal liability on corruption criminal offense and the obstacles of law enforcement. It also aims to analyze the regulations and its application in the future. This is normative research that uses literature review. It analyzes secondary data in the form of primary, secondary, and tertiary legal materials. The research results show: (1) criminal liability of political parties in corruption cases may only be demanded if the crime is carried out in the name of the political parties or if it is based on a mandate of that party; (2) the juridical factors which inhibits criminalization of political parties include the corruption regulations' incapability to penalize them, there are contradictive legal norms between that of corporations and political parties, and that not all corporate criminal sanctions may be imposed to political parties; and (3) it is hoped that the legal regulations on corruption may categorize political parties as corporations, to give a deterrent effect to political parties involved in corruption.
\end{abstract}

Keywords: Political Party; Corruption; Criminal Liability

\section{Introduction}

Political parties become the only institutions permitted to propose head of the region, legislative member, president, and vice president candidates in political contestation. This is in line with the research entitled, "Of The Extent of Corruption in Different Institutions Global Corruption Barometer 2013, " which stated that political parties and parliaments are part of the democratic institution that imposes great influence and great contribution to the people's lives, as they are the only political channels of citizens to obtain power in the parliament. The great functions and authorities of the political parties are highly fragile to misappropriation.

A form of misappropriation that happens is the corruption criminal offense that involves political party elites and public officials of political parties. The results of research from the Center of AntiCorruption Studies of Gadjah Mada University concluded that all political parties that have representatives in the Republic of Indonesia's Legislative House and those who hold the position as ministers in Indonesia Unifies Cabinet (Kabinet Indonesia Bersatu) of 2009-2014 are involved in corruption cases. ${ }^{2}$ Also, the

${ }^{1}$ Deborah Hardoon and Finn Heinrich, Global Corruption Barometer 2013 (Berlin: Transparency International, 2013 ), p. 16.

${ }^{2}$ Hukum Online, "Pukat: Seluruh Parpol Terlibat Korupsi," accessed on June $9^{\text {th }}, 2020$,

https://www.hukumonline.com/berita/baca/lt5329627e98607/pukat--seluruh-parpol-terlibat-kasus-korupsi/ 
results of a survey from the Global Corruption Barometer (GCB) from Transparency International show that $65 \%$ of Indonesian citizens regard the corruption rate as increasing from the last 12 months. ${ }^{3}$ Meanwhile, according to the data on profession/position-based corruption issued by The Indonesian Commission of Corruption Eradication (Komisi Pemberantasan Korupsi/KPK) on June $1^{\text {st }}$, 2020, the position of the Legislatives/Regional Legislatives are placed at the second-highest position (274 people) after private professions (308 people). ${ }^{4}$ This means that a relatively abundant number of political party elites who are representatives of the people in the parliament are involved in corruption cases.

The corruption crimes that involve political parties may be carried out by political party leaders in legislative and executive positions, as well as administrators and cadres of those political parties. ${ }^{5}$ Some corruption cases that happened in the political party environment include bribery to Mulut Tambang Riau-1 Steam Power Plant Project, bribery in the sales transaction of positions in the Ministry of Religion that involved the General Manager of Partai Persatuan Pembangunan (PPP/Party of Unified Development), bribery of imported beef that involved the President of Partai Keadilan Sosial (PKS/Party of Social Welfare), and bribery to the General Secretary of Partai Nasdem (National Democratic Party) as well as a member of Commission III. But in the perspective of law enforcement, as a legal entity, no political parties have been asked for criminal liability.

Based on the background above, the problems of the research are: (1) How is the political parties' criminal liability in the case of corruption? (2) What are the obstacles in enforcing the law towards political parties in the case of corruption? and (3) How should the regulations and the application of political party criminal liabilities be in future cases of corruption?

This is a normative or a literature type of research that is carried out by reviewing literature or secondary data, consisting of primary, secondary, and tertiary legal materials and by browsing online data. ${ }^{6}$ The data is then classified to make analyses and constructions ${ }^{7}$, then a contextual paradigm is used.

\section{Results and Discussion}

\section{Criminal Liability of Political Parties as Legal Entities in Corruption Cases}

The application of Law No. 31 of 1999 on the Eradication of Corruption Criminal Offense as changed into the Law No. 20 of 2001 on the change of the Law No. 31 of 1999 on the Eradication of Corruption Criminal Offense (hereinafter called the Law on Corruption Eradication) is deemed as nonoptimum in the context of corruption of political parties. No political parties have been imposed with criminal sanctions. Instead, only individual administrators are punished. Sudarto stated that the political dimension of criminal law aims to manifest criminal laws according to the current and the future conditions. ${ }^{8}$ Also, the formulation of corporate legal subjects in the Law on Corruption Eradication is a choice to create the best results of criminal law, meaning that it fulfills the requirements of justice and usability. ${ }^{9}$ The existence of corporate legal subjects emerges from the developments of society. ${ }^{10}$ As a

\footnotetext{
3 BBC Indonesia, "DPR 'Paling Korup' Menurut Persepsi Masyarakat Indonesia," accessed on June 23 $3^{\text {rd }} 2020$, https://www.bbc.com/indonesia/indonesia-39189729.

${ }^{4} \mathrm{KPK}, \quad$ "Graph TPK $\quad$ Berdasarkan Profesi/Jabatan," accessed on November 1 1 , 2020, https://www.kpk.go.id/id/statistik/penindakan/tpk-berdasarkan-profesi-jabatan.

${ }^{5}$ Sutan Remy Sjahdeini, Pertanggungjawaban Pidana Korporasi (Jakarta: GrafitiPress, 2006), p. 35.

${ }^{6}$ Mukti Fajar and Achmad Yulianto,Dualisme Penelitian Hukum Normatif dan Empiris (Yogyakarta: Pustaka Pelajar,2013),p. 170.

${ }^{7}$ Soerjono Soekanto, Pengantar Dasar-Dasar Penelitian Ilmu-Ilmu Sosial (Jakarta: Rajawali Press, 1986), p. $251-252$.

${ }^{8}$ Sudarto, Hukum Pidana dan Perkembangan Masyarakat: Kajian terhadap Pembaharuan Hukum Pidana (Bandung: Sinar Baru, 1983), p. 161.

${ }^{9}$ Ibid., p. 162.

${ }^{10}$ Paulus Aluk Fajar Dwi Santo, "Tinjauan tentang Subjek Hukum Korporasi dan Formulasi Pertanggungjawaban dalam Tindak Pidana," Humaniora 3, no 2 (2012): 426.
} 
political organization, political parties also run their functions for and in the name of their personal entity, making it inseparable from the essence of the legal subject with its rights and responsibilities. ${ }^{11}$

The formation of the corporate legal subject is basically rooted in the principle that the doer must be responsible. ${ }^{12}$ Thus, in the case of corruption, political parties must fulfill their criminal liability as it is their obligation to be responsible for the criminal activity they carried out. As the society's political aspiration group, political parties have political rationalization in running their functions. Also, in the case of a legal violation, they have their reasons as a corporation. They are able to act and be responsible for their criminal actions as well as their political rationalizations.

The characteristics of corporate criminal actions are similar to the corruption crime of political parties, especially that regarding bribery to political party leaders, as it gives political influence to public officials to issue policies that advantage the bribers. Political party officials (political party administrators, general managers, general secretary, etc. who have the power to create political party policies) use their power attributes as the party's representatives in undergoing criminal offense.

Political party corruption may happen if political party officials use the name of the party or their political influences from the party to obtain illegal profit or gratification. This action may be classified as a functional action of political party officials as the action is inseparable from their power in the political entity. In this case, political parties are deemed as corruptors through the corruption carried out by individuals in the parties' administration. The role of Eny Maulani Saragih in the case of to Mulut Tambang Riau-1 Steam Power Plant Project is in the form of participation with material perpetrators carried out by people with relatively smaller political power, but in the framework of authority imposition in the name of the political party.

Corruption crimes carried out jointly between political party administrators and other parties should be classified as a political party corruption criminal offense. In the participation offense, it may be seen from the scope of the political party corruption concerning the political party authority functions. As stated by Ali, ${ }^{13}$ there are two chances as to why criminal actions involve corporations and other legal entities (people). First, some corporate administrators and people outside of the corporation physically carry out the crime together. To determine whether or not there is a participatory offense, there needs to be further analysis to decide whether or not the corporate administrator carried out the crime under the scope and the authority functions of the corporation. If so, a participatory offense happened in this situation. Second, sometimes corporate administrators do not physically work together with other perpetrators during an illegal action. But all requirements and facilities are provided by the corporation, and that the provision of these things determine the success of the crime.

According to Article 11 clause (1) letter c of the Law on Political Parties, political functions in absorbing, collecting, and channeling political aspirations of the people in formulating and in determining the state policies. ${ }^{14}$ But, in several corruption cases - especially those related to bribery - this function is misused to obtain illegal rewards in the form of gifts or promises. This may be seen from the cases of political party corruptions that start from the imposition of political influence from political party officials to public officials in issuing policies that benefit certain parties with the reward of illegal gifts or promises. The cases above illustrate the existence of political party corruption crimes in the form of participatory offenses.

\footnotetext{
${ }^{11}$ Chidir Ali, Badan Hukum (Bandung: Alumni, 1999), p. 18-19.
}

12 Loebby Loqman, “Tanggung Jawab Pidana Korporasi dalam Tindak Pidana Lingkungan Hidup,” Diskusi Masalah-Masalah Prosedural dalam Penyelesaian Sengketa Lingkungan Kerjasama Sekretaris Kerjasama Relawan Pengadilan Perencanaan dan Majalah Hukum dan Pembangunan (Jakarta, 19-20 Juni 1989), p. 242.

${ }^{13}$ Mahrus Ali, Asas-Asas Hukum Pidana Korporasi (Jakarta: PT RajaGrafindo Persada, 2015), p. 85-86

${ }^{14}$ Article 11 clause (1) of the Law No. 2 of 2008 on Political Parties of the Republic of Indonesia. 
According to Ali, ${ }^{15}$ the functional behavior theory (functioneel daaderschap) and the identification theory (doctrinx of identification) may be used to determine the political parties' corruption crimes through the concept of corporate crimes. According to the functional behavior theory, as corporations cannot carry out the crimes alone, these actions are shifted to the corporate employees based on the stipulations that are strictly stated in the statutes and bylaws. Thus, according to this theory, the corruption crime of political parties is manifested through the actions of their administrators who have authority as stated in the statutes and bylaws. Thus, if a political party chairperson with his political power attributes as a political party administrator as stated in the statutes and bylaws of the political party corrupts, it means that the corruption crime is carried out by the political party. Then, according to the identification theory, a corporation is deemed as a crime perpetrator if a person identified with the corporation acts in the scope of her position. If that person carried out a criminal action in her capacity as an individual, this action is separate from the corporation.

There was the case of Setya Novanto, the Fraction Leader of Golkar Party (Golongan Karya/Party of Functional Groups) who gave his influence to EMS, a member of Commission VII of Golkar Party Fraction to help a businessman, Johanes Budisutrisno Kotjo, look for a project at PLN (Perusahaan Listrik Negara/State Electricity Enterprise). Then, EMS asked defendant IM as Acting General Manager of Golkar Party to give his influence as the Acting General Manager of Golkar Party to Kotjo to actualize his promise to give a fee for EMS' efforts as the Legislative House Commission VII member from the Golkar Fraction Party in helping him find the project and making him lead the Steam Power Plant Project from the State Electricity Enterprise. This shows that there is the misuse of party-related positions to obtain illegal income for the party's activities. Thus, in the perspective of the functional behavior theory, the actions of IM and EMS may be categorized as a corruption of the political party. Their authorities are stipulated in the statutes and bylaws as follows: Fractions are stipulated in the statutes Chapter XI Article 29, ${ }^{16}$ meanwhile, the position as the General Manager is regulated in the bylaws chapter V. Its structures and administration are regulated in Article 6 clause (1) letter a. ${ }^{17}$ According to the theory of behavioral identification, this action is also identified as an action of the political party.

Then, there were party-related relations in the corruption case of Romy who is the Chairperson of PPP (United Development Party), that made the political party obtain benefits in the form of the promise to enlarge the political party's influence, support, and budget for the campaign of that party's candidates. This corruption case involved three parties, and it may be identified as follows:

1. The political party chairperson influences a public officer who is a cadre of that political party as well as a civil service officer in a ministry, who is a subordinate of a public officer who is a cadre of that political party.

2. The public officer who is also a political party cadre was influenced by the political party officer to issue a policy in the appointment of the Head of the Provincial Area Office in a Ministry. The subordinate of the public officer who was influenced by the political party officer in issuing policies in appointing the Head of the Regency Office that may bring advantages to certain parties promised to give/gave gifts to the political party officer for his services in influencing the public officer and the subordinates in issuing policies.

3. Certain parties actively lobby to obtain profits from the issuing of the appointment decision in the positions as Head of the Provincial Area Office and Head of the Regency Office in a Ministry by giving/promising to give gifts to the political party officials who have influenced the public officer who is also a political party cadre.

\footnotetext{
${ }^{15}$ Mahrus Ali, Asas-Asas Hukum, p. 78-80.

${ }^{16}$ General Election Commission, "Keputusan Musyawarah Nasional Luar Biasa Partai Golongan Karya Tahun 2016 Nomor: VI/MUNASLUB/GOLKAR/2016 tentang Perubahan Anggaran Dasar dan Anggaran Rumah Tangga Partai Golkar," accessed on June 29 ${ }^{\text {th }}$, 2021, https://infopemilu.kpu.go.id/download/verpol/131/ADART\%20PARTAI\%20GOLKAR(1).pdf

${ }^{17}$ National Extraordinary Deliberation of Golkar Party No: VI/MUNASLUB/GOLKAR/2016 on the Change of the Statutes and Bylaws of Golkar Party.
} 
The researcher suggests that this case may be identified as a political party corruption as there are functional actions of the political parties and that there are promises of votes or financial supports for the candidates from that political party. According to the functional behavior theory, this is a corruption of the political party as defendant Romy, who is the Chairperson of PPP (United Development Party) ex officio Head of the A'la High Assembly and Lukman Hakim Saifuddin who is head of the Pakar assembly and Indonesia's Ministry of Religion ${ }^{18}$ and other parties bribed in the selection process of the Head of the Provincial Area Office in a Ministry. Their positions are regulated in the statutes and bylaws; ${ }^{19}$ thus, their actions are identified as a corruption of the political party. Moreover, the party received benefits in the form of promises, vote support, and financial support.

Then, in the case of Defendant LHI, it is interesting to analyze the judge's consideration, "To give his services to the witness Maria Elizabeth Liman, LHI needs not to have the authority himself to issue a recommendation on the increase of imported beef quota. It is enough to use his position as Republic of Indonesia's Legislative House member from PKS Party (Partai Keadilan Sejahtera/Party of Just Welfare) as well as the Chairperson of that Party. This is because the Ministry of Agriculture position was filled by a PKS leader, namely the witness Suswono." LHI uses his positions to influence the Ministry of Agriculture from the same party as his to increase the imported beef quota to Liman. Because of that, LHI obtained a commitment fee of 40 billion rupiahs (there is a commitment fee of Rp. 5 thousand for every kilogram of imported beef which reached 8.000 tons). Part of this fee has been given through Ahmad Fathanah from Liman (General Director of PT Indoguna Utama) with the amount of Rp 1.300.000.000.

The case of LHI in 2013 shows that a political party's leader may influence the decisions of that party's cadres in strategic positions. According to the functional behavior theory, the corruption of the political party is manifested through the actions of LHI as the PKS chairperson, the Ministry of Agriculture, and other bribing parties. The position as a party leader is regulated in the statutes and bylaws. ${ }^{20}$ According to the behavioral identification theory, these actions are regarded as political party corruption as LHI uses his political relations to influence a cadre of his party.

These corruption cases of political parties are often due to the parties' dominant power. Political parties have the factor of power based on their authorities to place their representatives in branches of the state authority, especially in the executive and legislative institutions as stipulated in Article 12 letters d, e, f, g, h, and I as well as the Law No. 2 of 2011 on the Change of the Law No. 2 of 2008 on Political Parties (namely the Law on Political Parties). This factor of power may be the main factor of corruption. The political parties' great role and service in placing their representatives in strategic positions bring impacts to the political parties' political interests. Thus, the political party delegations in strategic positions may be demanded to strive for the political parties' political interests.

One of the main aims of political party corruption is to fund the party's activities. ${ }^{21}$ Usually, the political party justifies the corruption with the excuse of lack of financial resources to fund the party's organization. This happened in the cases of IM, Saragih, and Romy.

In this case, the application of the "No punishment without guilt" principle in the political party corruption may be seen from the actions of the political party official of administrators in running their functionary tasks and the series of their actions, starting from influencing the public officials to issue

\footnotetext{
${ }^{18}$ General Election Commission, "Keputusan Menteri Hukum dan Hak Asasi Manusia RI Nomor: M.HH-10.AH.11..01 Tahun 2018 tentang Pengesahan Perubahan Susunan Kepengurusan Dewan Pimpinan Pusat Partai Persatuan Pembangunan Masa Bakti 2016-2021," accessed on June 29 ${ }^{\text {th }}$, 2021, https://jdih.kpu.go.id/data/data_parpol/AD\%20ART\%20PPP\%202019.pdf.

${ }^{19}$ UKM Riau, "Ketetapan Muktamar VIII Partai Persatuan Pembangunan No: 07/TAP/MUKTAMAR VIII/PPP/2016 Tentang Perubahan Anggaran Dasar Dan Anggaran Rumah Tangga Partai Persatuan Pembangunan,” accessed on June 29 ${ }^{\text {th }}$, 2021, https://www.ukmriau.com/wp-content/uploads/2017/10/AD_ART-PPP.pdf

${ }^{20}$ Partai Keadilan Sejahtera, “Anggaran Dasar Dan Anggaran Rumah Tangga Partai Keadilan Sejahtera," accessed on June 29th 2021, https://pks.id/resources/documents/AD-ART\%20PKS.pdf.

${ }^{21}$ Nasional Tempo, "Politikus Golkar: Dana Parpol Minim Salah Satu Penyebab Korupsi," accessed on June 28 ${ }^{\text {th }}$, 2021, https://nasional.tempo.co/read/1046140/politikus-golkar-dana-parpol-minim-salah-satu-penyebab-korupsi 
policies for their advantage with illegal gifts in return. The illegal profits they obtain are used for the political parties' operational activities. Whether or not the political parties carry it out, the action is represented by the administrators of the political party's activities. Thus, this principle may be imposed on political parties as a guarantee for the protection of human rights.

The political parties' criminal liability on corruption may be demanded if the crime is carried out for the sake of that party or due to the mandate of that party. But it cannot be demanded if the crime is an individual action of a political party member or administrator for other reasons and that the benefits are not obtained by the political parties.

\section{Obstacles in Enforcing Anti-Corruption Laws to Political Parties}

Some juridical factors become obstacles in enforcing anti-corruption laws to political parties: (1) the criminal actions of political parties as corporations cannot yet be reached by-laws that regulate corruption, (2) there are conflicting regulating norms on corporations in the Law on Corruption Eradication and those on political parties in the Law on Political Parties, and (3) the corporate criminal sanctions in the Law on Corruption Eradication cannot usually be applied to political parties.

The scope of crime that may be carried out by political parties are regulated in Article 40 clauses (2) and (3) of the Law on Political Parties as follows:

Clause (2): Political Parties are prohibited from:

a. carrying out actions that violate the Republic of Indonesia's 1945 Constitution and laws; or

b. carrying out actions that endanger the unity and the safety of the Republic of Indonesia Unified State. Clause (3): Political Parties are prohibited from:

a. receiving from or giving to other parties gratification in any form that violates the law;

b. receiving gratification in the form of money, items, or services from other parties without a note on clear identification;

c. receiving gratification from individuals and/or companies/businesses more than that stipulated in the law;

d. asking for or receiving funds from state-owned business enterprises, regional government-owned business enterprises, and village-owned business enterprises, or those of other terms; or

e. using the fraction at the People's Consultative Assembly, People's Representative Assembly, Regional People's Representative Assembly of the Province, Regional People's Representative Assembly of Cities/Regencies as sources of political party funding.

The scope of legal violations strictly stated in the Law on Political Parties implies that the corruption offense stated in the Law on Corruption Eradication to political parties as corporations cannot be imposed as the parties' violations are only those regulated in the Law on Political Parties. Implicitly, the corruption cases that involve the defendants IM, Romy, and LHI show the actions of political party officials as the representatives of those parties that give political influence to public officials from those parties to issue some policies that illegally benefit certain parties. This illegal influence imposition is a misuse of the political party's power by utilizing the party's cadres in executive or judicative institutions. But, those actions are argued as not criminal offenses, but they are deemed as violations of the Law on Political Parties. It implies that the political parties cannot be punished.

On the contrary, Article 40 clause (2) letter a of the Law on Political Parties strictly prohibits political parties from carrying out actions that are against the constitution and the legal regulations that apply. In this context, it may become a juridical justification of the punishment to political parties as a corporation that is a subject of corruption offense through the application of the Law on Corruption Eradication. Considering that the regulation on violations in this Article is widely extensive, thus it may be 
categorized as a violation of law as stated in the Law on Corruption Eradication ${ }^{22}$. Thus, a political party's actions that fulfill the formulation of corruption offense as stated in the Law on Corruption Eradication may not be deemed as violating the Law on Political Parties. Then, political parties are prohibited from using the fractions in the People's Consultative Assembly, People's Representative Assembly, Regional People's Representative Assembly of the Province, Regional People's Representative Assembly of Cities/Regencies as sources of political party funding as stated in clause (3) letter e of this law. This is highly relevant to the parties' corruption as a justification of their misuse of power to corrupt.

Article 20 of the Law on Corruption Eradication has not yet strictly stated how and when corporations and their administrators may be demanded the corporations' corruption criminal liability. This lack of criteria implies three things: (1) judges or general prosecutors may only determine corporate administrators as perpetrators who are responsible for the crime, even though facts in court show that the main actor of that crime is the corporation, (2) the threat of heavy punishment in the formulation of laws directed to corporations does not mean anything if only the administrators may be deemed as responsible, (3) the lack of criteria may become a criminogenic facto, where corporate criminal actions increase in the aspects of quality and quantity. ${ }^{23}$

How and when corporations and their administrators may be demanded the corporations' criminal liability of corruption is actually regulated in the Republic of Indonesia's Decree of Attorney General No. PER-028/A/JA/10/2014 on the Guidelines to Handle Criminal Cases with Corporate Legal Subjects (hereinafter named DAG Corporation). Chapter II of this law stipulates the Criteria of Actions as follows:

A. Corporate actions that may be demanded with criminal liability.

1. Criteria of the actions that may be demanded with criminal liability on corporations are regulated in the laws that apply.

2. The criteria in number (1) are the fulfillment of these qualifications:

a. All forms of actions based on the decision of Corporate Administrators that act or that participate in the action;

b. All forms of actions whether or not carried out by someone for the corporation's interests, either due to their work and/or other relations;

c. All types of actions that use human resources, funds, and/or all types of support or facilities from the corporation;

d. All types of actions carried out by the third party due to demands or orders of the corporation and/or its administrators;

e. All types of actions in carrying out the corporation's daily activities;

f. All types of actions that advantage the corporation;

g. All types of actions that are accepted/usually accepted by that corporation;

h. A corporation that factually accommodates criminal proceeds with a corporate legal subject; and/or

i. Other forms of action may be demanded with corporate liability according to the law.

B. Actions of the corporate administrators that may be demanded with criminal liability.

1. Every person who does, participates in, orders others to participate in, recommends participation in, or helps to do criminal actions;

2. Every person who has the power and the authority to prevent that criminal action but fails to take that step and realizes that he/she will be imposed with great risk if that criminal action happens;

${ }^{22}$ Explanation of Article 2 clause (1) of the Law on Corruption Eradication of the Republic of Indonesia.

${ }^{23}$ Hanafi Amrani and Mahrus Ali, Sistem Pertanggungjawaban Pidana: Perkembangan dan Penerapan, (Jakarta: PT RajaGrafindo Perkasa, 2015), p. 185. 
3. Every person who has knowledge on the great risk and if he/she knows that the criminal action is carried out by a corporation, and/or

4. Other forms of action that may be demanded liability to the corporate administrators according to the law.

A problem with the application of prioritized laws arises as the DAG Corporation is hierarchically under other laws such as the Law on Corruption Eradication. Moreover, the DAG Corporation only applies to the General Prosecutor, meanwhile, Judges and Police Investigators are not obliged to obey it.

A problem with the punishment of political parties in the context of corporate criminal liability in the case of corruption is that only fines may be imposed as the principal punishment and the additional punishments are deemed as unsuitable to the political parties' characteristics. Article 20 clause (7) of the Law on Corruption Eradication states that "The principal punishment that may be imposed to corporations are only fines, with the maximum punishment stipulation of an additional 1/3 (third)". There are regulations on the revocation of certain rights or profits from the government to the perpetrator as regulated in Article 18 clause (1) letter $\mathrm{d}$ of the Law on Corruption Eradication. At a glance, the additional punishment may be seen as not obligatory, but it is only an option that may be imposed on corruptors. It means that the stipulation on additional punishments is not essential in imposing criminal punishments, this is related to the characteristics of the crime and the deterrent effect that will be imposed on the perpetrators. ${ }^{24}$ This shows that the principal punishment in the form of a fine and the additional punishments may become the most detrimental factors in achieving the goals of punishment in the context of corruption with corporations as the offense subjects.

The implementation factor that becomes the obstacle in enforcing the law to political parties in corruption criminal offense cannot be separated from the juridical factor. On one hand, law enforcers do not yet have legal certainly in classifying political parties in the corporate category as stated in the Law on Corruption Eradication. On the other hand, the corporate regulations in Article 1 number 1 of this law may be interpreted as including political parties. Next, it is still difficult for the law enforcers to fulfill the two absolute requirements of punishing, namely actus reus and mens rea.

The problem regarding these absolute requirements is that there is an argument that it is dangerous to be able to punish corporate offense subjects as there is neither conscience nor inner attitude on the wrongness as an absolute requirement that must be proven by the General Prosecutor in Court, even though the criteria of corporate wrongness have been formulated in Article 4 clause (2) on the Decree of the Supreme Court No. 13 of 2016 on Guidelines to Handle Criminal Cases with Corporate Legal Subjects (hereinafter named DSC Corporation). Thus, the effectivity of the construction of understanding on the type of wrongness in that regulation must be questioned in handling political parties' corruption cases, considering that there have not been any corruption cases that involve political parties as corporations who are demanded criminal liability through that DSC Corporation.

Next, in the case of imposing the criminal sanctions that suit the political parties' characteristics, law enforcers face trouble as the types of punishments stipulated in the Law on Corruption Eradication are deemed as unsuitable with the political parties' characteristics as corporations in a corruption case. An example regards the dissolution of political parties, which is not the domain of criminal court but is an absolute competence of the Constitutional Court ${ }^{25}$. Apart from that, there is the chance for law enforcers to experience other problems from the non-juridical aspects.

Issues of legal and political sovereignty come up in enforcing the law to political parties in corruption cases. The influence of power can neither be separated from it - worse, it may even exhibit great

${ }^{24}$ Basaria Panjaitan, "Kaitan Efek Jera Penindakan Berat terhadap Kejahatan Korupsi dengan Minimnya Pembangunan Infrastruktur dan Penyerapan Anggaran Daerah,” Makalah (Jakarta, 4 Desember 2015), p. 1.

${ }^{25}$ Article 10 clause (1) letter c of the Law No. 23 of 2004 on the Constitutional Court of the Republic of Indonesia. 
pressure. Thus, it is as if legal sovereignty is powerless in controlling the corrupt power - causing social apathy. The power is characterized as monopolistic and hates to be competed or outperformed by other parties. Thus, it also dislikes being competed by legal sovereignty that controls and adjudicates. ${ }^{26}$

Another obstacle is that the national leadership lacks strict partiality towards anti-corruption movements. Political interest calculations often become the reason; thus, they are reluctant to impose strict actions on the corrupt political parties. This is because strict acts of the elite are deemed to only cause political turbulence that disrupts development. ${ }^{27}$ Conceptually, intervention is still required to maintain independence and effectiveness in eradicating corruption, especially when the big targets (big fishes) bend the substance of truth in law enforcement. ${ }^{28}$

For example, in the case of IM and Saragih, if referring to the Law on Corruption Eradication, the return of the proceeds from corruption does not eradicate their criminal liability. ${ }^{29}$ But in reality, if the corrupted money is returned in the name of the political party administrators, the political parties are not demanded to provide criminal liability. It is not seldom that punishments are decreased through the remission proposal process for the party colleagues through the Ministry of Law and Human Rights. This practice also happened in the United States when President Gerald Ford gave clemency to Richard Nixon who is his colleague in the political party, who was responsible for the Watergate Scandal. ${ }^{30}$

\section{Legal Regulations and Application on Political Parties' Corruption Criminal Liability in the Future}

The parameters to determine the political parties' criminal liability are the corporate categories, Law on Corruption Eradication, DAG Corporation, and the DSC Corporation, which define corporations as, "A group of organized people and/or wealth, either incorporated or not."

DSC Corporation Article 1 number 8 states that corporate criminal action is, "A criminal action that may be demanded with corporate criminal liability according to the laws that regulate corporations." The aforementioned law is still unclear, but it may refer to the Law on Corruption Eradication.

The guilt of political parties as corporations is different from that of human legal subjects. As argued by Huda, "The basis in determining corporate guilt is the failure to fulfill the corporations' social functions well." The indicator of this failure includes but is not limited to preventing criminal actions. ${ }^{31}$ The political parties' social functions are explicitly regulated in Article 11 clause (1) letter $\mathrm{b}$ of the Law on Political Parties, which states, "Political parties function as a facility in creating a conducive climate for the unity and the harmony of the Indonesian nation for social welfare." Corruption criminal offenses of political parties through their administrators show that they fail to run their social functions well. In doing so, they also fail to create a conducive climate in the state.

The criteria as to when and how a political party as a corporation may be demanded with corruption criminal liability may refer to the DAG Corporation, where corporations may be responsible as a perpetrator apart from natural people (natuurlijik persoon).

\footnotetext{
${ }^{26}$ Artidjo Alkostar, Korupsi Politik di Negara Modern (Yogyakarta: FH UII Press, 2015), p. 122.

27 Tangri and Mwenda in Ahmad Khoirul Umam, Pergulatan Demokrasi dan Politik di Indonesia (Yogyakarta: Pustaka Pelajar, 2014), p. 39.

${ }^{28}$ Ibid., p. 39.

${ }^{29}$ Article 4 of the Law on Corruption Eradication of the Republic of Indonesia.

${ }^{30}$ Liputan 6, "Pengampunan Tanpa Syarat Presiden AS Gerald Ford pada Richard Nixon," accessed on December 27 $7^{\text {th }}, 2020$, https://www.liputan6.com/global/read/4350126/8-9-1974-pengampunan-tanpa-syarat-presiden-as-gerald-ford-pada-richardnixon.

${ }^{31}$ Chairul Huda in Ali, Asas-Asas Hukum, p. 153. 
Article 20 clause (7) of the Law on Corruption Eradication that states, "The principal punishment that may be imposed to corporations are only fines, with the maximum punishment stipulation of an additional 1/3 (a third)," is deemed to not have a deterrent effect to political parties that corrupt. Some argue that the most effective way is to impose the sanction of political party dissolution. ${ }^{32}$ Even so, the dissolution of political parties is an absolute competence of the Constitutional Court. It is not the authority of the criminal court. Thus, the writer suggests that apart from fines, the corrupt political parties may be imposed with the principal sanctions in the form of the prohibition from participating in general elections and prohibition from obtaining funds from the government for a certain period.

Even so, the principal sanction in the form of fines is quite relevant to corporations, even though it contains some weaknesses. Regarding that, Ali opines that multiplying fines may prevent corporations from carrying out criminal actions. ${ }^{33}$ Ali suggests that this system is based on social welfare. The imposition of the fines may be carried out by considering the amount of profit the corporation obtained through illegal actions, subtracted by the loss from that action, and the expenditures spent in enforcing the law. ${ }^{34}$ Based on the perspectives above, the writer suggests some changes in the amendment of the Law on Corruption Eradication (Article 20) as follows:

1. Clause (1), "A crime is carried out by a corporation if it is carried out by a person who has a functional position in the corporate structural organization that ats for and/or in the name of the corporation of for the interest of the corporation, both based on work relations or other relations, in the scope of that corporation, individually or collectively."

2. Clause (2), "Corporations may be demanded criminal liability on actions carried out for and/or in the name of the corporation if that action is part of its businesses' scope that is determined in the statutes and other stipulations that apply to that corporation."

3. Clause (3), "If the criminal action is carried out by a corporation, the criminal liability is imposed to the corporation and/or the administrators."

4. Clause (5), "The criminal liability of corporate administrators may be imposed to those who have functionary positions in the corporate structural organization and to those who do not or to other people that obtain benefits or to the people that become the corporate controlling personnel."

5. Clause (8), "The principal sanctions that may be imposed to the corporations are multiplying fines, the prohibition from participating in general elections for a certain period and the prohibition from obtaining funds from the state or financial support from external parties including individuals and business entities for a certain period."

6. Explanation of clause (4), "The imposition of the multiplying fine sanction is carried out by multiplying the amount of loss caused by the corporate corruption with the amount spent by the state to the corporations in the form of financial support or other incentives as it is deemed that the corporation fails to run its functions well, especially in preventing corruption criminal offense and the amount spent in enforcing the law towards corporations' criminal actions."

The suggested formulation above may be considered, considering that political parties are a dominating entity, as most corruption cases involve perpetrators with political power. The perpetrators wear party attributes or are affiliated with parties. Sometimes political corruption cases indicate that the proceeds are directed to illegally fund political parties' activities. Thus, to enforce the law and justice, the criminal liability of political parties as corporations that corrupt is crucial, considering that there are already many stipulations that regulate corporations, using the term "corporations" to call recht person.

\footnotetext{
32 Chairul Huda, "Pertanggungjawaban Partai Politik sebagai Korporasi dalam Sistem Hukum Pidana Indonesia," Studium Generale (Fakultas Hukum UII Jogjakarta, 11 July 2019).

${ }^{33}$ Ali, Asas-Asas Hukum, p. 268.

${ }^{34}$ Nuno Garoupa and Daniel Klerman in Ali, Asas-Asas Hukum, p. 268-269.
} 


\section{Conclusion}

From the results of this research, the writer concludes that criminal liability of political parties in corruption criminal offense may be demanded by the political parties if the corruption is carried out for and/or in the name of the political party or based on the mandate from that party. There are factors in the juridical perspective and in the implementation of regulations that serve as the obstacles in law enforcement towards political parties in corruption offenses. In the future, the regulation and the law enforcement on political parties' criminal liabilities in corruption starts from the interpretation of political parties as a type of corporation.

Then, the writer suggests that the criminal code bill on corporate criminal actions and corporate criminal liability that is more comprehensive, that accommodates corporations as criminal law subjects, and that adds principal criminal sanctions suitable with corporate characteristics is passed. Also, the amendment of the Law on Corruption Eradication adds corporate criminal liability criteria and the principal criminal sanctions that may be imposed.

\section{Bibliography \\ Books}

Ali, Chidir. Badan Hukum. Bandung: Alumni, 1999.

Ali, Mahrus. Asas-Asas Hukum Pidana Korporasi. Jakarta: PT RajaGrafindo Persada, 2015.

Alkostar, Artidjo. Korupsi Politik di Negara Modern. Yogyakarta: FH UII Press, 2015.

Amrani, Hanafi and Mahrus Ali Sistem Pertanggungjawaban Pidana: Perkembangan dan Penerapan. Jakarta: PT RajaGrafindo Perkasa, 2015.

Fajar, Mukti and Achmad Yulianto. Dualisme Penelitian Hukum Normatif dan Empiris Yogyakarta: Pustaka Pelajar, 2013.

Hardoon, Deborah and Finn Heinrich. Global Corruption Barometer 2013. Berlin: Transparency International, 2013.

Sjahdeini, Sutan Remy. Pertanggungjawaban Pidana Korporasi. Jakarta: GrafitiPress, 2006.

Soekanto, Soerjono. Pengantar Dasar-Dasar Penelitian Ilmu-Ilmu Sosial. Jakarta: Rajawali Press, 1986.

Sudarto. Hukum Pidana dan Perkembangan Masyarakat: Kajian terhadap Pembaharuan Hukum Pidana. Bandung: Sinar Baru, 1983.

Umam, Ahmad Khoirul. Pergulatan Demokrasi dan Politik di Indonesia. Yogyakarta: Pustaka Pelajar, 2014.

\section{Laws}

Law No. 2 of 2008 on Political Parties of the Republic of Indonesia.

National Extraordinary Deliberation of Golkar Party No: VI/MUNASLUB/GOLKAR/2016 on the Change of the Statutes and Bylaws of Golkar Party.

Explanation of Article 2 clause (1) of the Law on Corruption Eradication of the Republic of Indonesia.

Law No. 23 of 2004 on the Constitutional Court of the Republic of Indonesia.

Law No. 31 of 1999 on the Eradication of Corruption Criminal Offense as changed into the Law No. 20 of 2001 on the change of the Law No. 31 of 1999 on the Eradication of Corruption Criminal Offense of the Republic of Indonesia.

\section{Journal}

Santo, Paulus Aluk Fajar Dwi. "Tinjauan tentang Subjek Hukum Korporasi dan Formulasi Pertanggungjawaban dalam Tindak Pidana.” Humaniora 3, no 2 (2012): 426.

\section{Proceedings}

Huda, Chairul. "Pertanggungjawaban Partai Politik sebagai Korporasi dalam Sistem Hukum Pidana Indonesia." Studium Generale (Fakultas Hukum UII Jogjakarta, 11 July 2019). 
Loqman, Loebby. “Tanggung Jawab Pidana Korporasi dalam Tindak Pidana Lingkungan Hidup.” Diskusi Masalah-Masalah Prosedural dalam Penyelesaian Sengketa Lingkungan Kerjasama Sekretaris Kerjasama Relawan Pengadilan Perencanaan dan Majalah Hukum dan Pembangunan (Jakarta, 19-20 Juni 1989), p. 242.

Panjaitan, Basaria. "Kaitan Efek Jera Penindakan Berat terhadap Kejahatan Korupsi dengan Minimnya Pembangunan Infrastruktur dan Penyerapan Anggaran Daerah.” Makalah (Jakarta, 4 Desember 2015), p. 1.

\section{Websites}

BBC Indonesia. "DPR 'Paling Korup' Menurut Persepsi Masyarakat Indonesia," accessed on June $23^{\text {rd }}$, 2020, https://www.bbc.com/indonesia/indonesia-39189729.

General Election Commission. "Keputusan Menteri Hukum dan Hak Asasi Manusia RI Nomor: M.HH10.AH.11..01 Tahun 2018 tentang Pengesahan Perubahan Susunan Kepengurusan Dewan Pimpinan Pusat Partai Persatuan Pembangunan Masa Bakti 2016-2021," accessed on June 29 , 2021, https://jdih.kpu.go.id/data/data_parpol/AD\%20ART\%20PPP\%202019.pdf.

General Election Commission. "Keputusan Musyawarah Nasional Luar Biasa Partai Golongan Karya Tahun 2016 Nomor: VI/MUNASLUB/GOLKAR/2016 tentang Perubahan Anggaran Dasar dan Anggaran Rumah Tangga Partai Golkar," accessed on June 29 ${ }^{\text {th }}$ 2021, https://infopemilu.kpu.go.id/download/verpol/131/ADART\%20PARTAI\%20GOLKAR(1).pdf

Hukum Online. "Pukat: Seluruh Parpol Terlibat Korupsi," accessed on June $9^{\text {th }}, 2020$, https://www.hukumonline.com/berita/baca/lt5329627e98607/pukat--seluruh-parpol-terlibat-kasuskorupsi/

KPK. "Graph TPK Berdasarkan Profesi/Jabatan," accessed on November $1^{\text {st }}, 2020$, https://www.kpk.go.id/id/statistik/penindakan/tpk-berdasarkan-profesi-jabatan.

Liputan 6. "Pengampunan Tanpa Syarat Presiden AS Gerald Ford pada Richard Nixon," accessed on December $27^{\text {th }}$, 2020, https://www.liputan6.com/global/read/4350126/8-9-1974-pengampunan-tanpasyarat-presiden-as-gerald-ford-pada-richard-nixon.

Nasional Tempo. "Politikus Golkar: Dana Parpol Minim Salah Satu Penyebab Korupsi," accessed on June $28^{\text {th }} ， 2021$, https://nasional.tempo.co/read/1046140/politikus-golkar-dana-parpol-minim-salahsatu-penyebab-korupsi

Partai Keadilan Sejahtera. "Anggaran Dasar Dan Anggaran Rumah Tangga Partai Keadilan Sejahtera," accessed on June $29^{\text {th }}$, 2021, https://pks.id/resources/documents/AD-ART\%20PKS.pdf.

UKM Riau. "Ketetapan Muktamar VIII Partai Persatuan Pembangunan No: 07/TAP/MUKTAMAR VIII/PPP/2016 Tentang Perubahan Anggaran Dasar Dan Anggaran Rumah Tangga Partai Persatuan Pembangunan," accessed on June 29 , 2021, https://www.ukmriau.com/wpcontent/uploads/2017/10/AD_ART-PPP.pdf

\section{Copyrights}

Copyright for this article is retained by the author(s), with first publication rights granted to the journal.

This is an open-access article distributed under the terms and conditions of the Creative Commons Attribution license (http://creativecommons.org/licenses/by/4.0/). 